\title{
O modelo Funcionalista de Christiane Nord aliado ao dispositivo de Sequências Didáticas: norteamentos para o Ensino de Tradução
}

\section{Christiane Nord's functionalist model combined with the didactic sequence device: directions for translation teaching}

\author{
Valdecy de Oliveira Pontes \\ Universidade Federal do Ceará, Fortaleza, Ceará / Brasil \\ valdecy.pontes@ufc.br \\ Livya Lea de Oliveira Pereira \\ Universidade Federal do Ceará, Fortaleza, Ceará / Brasil \\ livyalea010@hotmail.com
}

Resumo: Abordagens mais recentes nos Estudos da Tradução partem do princípio de que não se traduz uma língua/cultura, mas textos. $\mathrm{Na}$ perspectiva da Tradução Funcionalista, esses não podem ser compreendidos à parte de seu contexto comunicativo, fato que justifica a proximidade do Ensino de Tradução com o conhecimento sobre gêneros textuais, destacada, inclusive, por Nord (2012). Assim, a partir da perspectiva teórica funcionalista de Christiane Nord (1991, 1994, 1996, 2012) para o ensino de tradução e da contribuição da Linguística de Texto acerca do funcionamento e domínio dos gêneros textuais, este trabalho discorre sobre a aplicação de Sequências Didáticas (SD) na formação de tradutores. Para tanto, percorre o seguinte percurso teórico-metodológico: 1. pontuar direcionamentos teóricos a respeito do Ensino de Tradução Funcionalista com base em Nord (1991, 1994, 1996, 2012); 2. discorrer sobre a elaboração e aplicação dos dispositivos de SD, baseando-se nas contribuições de Dolz e Schneuwly (1998), Cristóvão (2009, 2010), etc.; 3. ilustrar um projeto inicial de SD, com o gênero textual peça de 
teatro, para futuros tradutores, no par linguístico espanhol-português, incluindo a modelização do gênero, por meio da análise de dez peças hispânicas e brasileiras. Por meio deste percurso, o trabalho pretende mostrar que a proposta de SD, contemplando os direcionamentos do ensino da tradução funcionalista, poderá proporcionar ao futuro tradutor conhecimento sobre os diferentes gêneros textuais e seu funcionamento nas distintas culturas envolvidas na tradução, além de possibilitar: (i) o desenvolvimento de capacidades de linguagem na língua-base e na língua-meta; (ii) a compreensão da tradução como um processo circular.

Palavras-chave: tradução; modelo funcionalista; sequências didáticas.

Abstract: Recent approaches in Translation Studies assume that languages/ cultures are not translated, texts are. In the perspective of Functionalist Translation, texts are not understood isolated from their communication context, which justifies the proximity of Translation Teaching with the knowledge of genres suggested by Nord (2012). Considering Nord's functionalist theoretical perspective for translation teaching and Text Linguistic contribution on the operation and control of genres, this paper discusses the application of Didactic sequences (SD) in translators' training. In order to do that, the following theoretical and methodological guidelines are used: 1. pinpoint theoretical directions for the Functionalist Translation Teaching based on Nord (1991, 1994, 1996, 2012); 2. discuss the development and implementation of SD devices, based on the contributions of Dolz and Schneuwly (1996), Cristóvão $(2009,2010)$ among others; 3. exemplify an initial didactic sequence project about the theater genre for future translators in the Spanish-Portuguese linguistic pair, including modeling of the genre, through the analysis of 10 Hispanic and Brazilian pieces. It is expected that the SD proposed, contemplating the directions of Functionalist Translation Teaching, can provide the translator with knowledge on different genres and on its functioning in different cultures involved in the translation process, in addition to the development of language skills in both the source and the target languages and the understanding of translation as a circular process.

Keywords: Translation; Functionalist model; Didactic sequences.

Recebido em: 23 de abril de 2016. Aprovado em: 24 de agosto de 2016. 


\section{Introdução}

Por muito tempo, o ato tradutório foi permeado por uma visão formalista, o que significava entender a tradução, muitas vezes, como equivalência linguística, nos âmbitos frasal e lexical, e, ainda, priorizava-se a manutenção do significado (sentido) do texto base (original) (ROMÃO, 2010a). Contudo, nos anos 70, sob a influência da perspectiva linguística funcionalista, além do desenvolvimento da Pragmática Linguística, Sociologia e Antropologia Cultural, surge, no âmbito dos Estudos da Tradução, a vertente alemã conhecida como Teoria Funcionalista da Tradução ou Tradução Funcionalista. Essa busca se desprender do puramente linguístico para incluir aspectos contextuais, culturais e interacionais na tradução. Nessa teoria, não se traduzem palavras, mas funções comunicativas.

Para a Tradução Funcionalista, o texto é entendido como um evento comunicativo, localizado em tempo e lugar, que possui, pelo menos, dois interlocutores em condições apropriadas e dispostos a se comunicar para alcançar um objetivo concreto. Desse modo, segundo Nord (2012, p. 2), mesmo os primeiros tradutores da vertente alemã já concordavam que sem uma análise adequada do texto, o tradutor nunca poderá compreender todos os seus aspectos, muito menos, traduzi-los. Por isso, considerando que tal análise auxilia na compreensão ampla e profunda do texto, além de facilitar a tomada de decisões do tradutor, Nord $(1991,1994,2012)$ propõe um modelo de análise pré-translativo, ${ }^{1}$ o qual contempla aspectos intra e extratextuais, além dos efeitos comunicativos, do texto base (doravante, TB) e texto meta (TM).

A partir desse contexto, busca-se discorrer acerca da possibilidade de elaboração e aplicação de Sequências Didáticas (SD), levando em conta o modelo da Tradução Funcionalista para a formação de tradutores, posto que uma SD é um conjunto de atividades escolares organizadas de maneira sistemática, em torno de um gênero textual oral ou escrito, visando à apropriação e domínio de gêneros textuais" (DOLZ; NOVERRAZ; SCHNEUWLY, 2004, p. 96). Sobre essa temática, Nord (2012) assevera que o estudo e o agrupamento de gêneros, tipos e

\footnotetext{
${ }^{1}$ Sobre o termo 'translação', trata-se de uma nomenclatura mais abrangente, especificada por Reiss e Vermeer (1996) e utilizada por Nord (2012), para englobar tanto a tradução escrita quanto a interpretação (tradução oral). Neste artigo, utilizaremos os termos tradução e 'translação' como sinônimos.
} 
classes de textos, de acordo com as suas características típicas, auxilia no trabalho do tradutor.

Com o objetivo de analisar essa questão, apresentar-se-ão as seguintes seções: 1 Introdução; 2 A Tradução Funcionalista e a Formação de Tradutores; 3 A elaboração de SD aplicadas ao ensino de Tradução; 4 Proposta de SD a partir da tradução funcional do gênero textual peça de teatro; 5. Considerações finais e Referências. Na próxima seção, serão expostos alguns conceitos basilares da Tradução Funcionalista, além de direcionamentos acerca do ensino da tradução, na perspectiva funcional.

\section{A Tradução Funcionalista e a Formação de Tradutores}

Reiss e Vermeer (1996, p. 96), dois dos principais teóricos e difusores da Tradução Funcionalista, postularam os conceitos basilares dessa teoria, os quais podem ser resumidos da seguinte forma: 1. A translação está em função de seu objetivo/finalidade (skopos); 2. A translação é uma oferta informativa em uma cultura final e em sua língua sobre uma oferta informativa procedente de uma cultura de origem e de sua língua; 3. a oferta informativa de uma translação se apresenta como transferência que reproduz uma oferta informativa de partida. Essa reprodução não é reversível de um modo unívoco. Esses conceitos se apresentam de forma hierárquica, portanto, o objetivo da translação determina todo o processo tradutório.

Observa-se, também, nos conceitos apresentados, a relevância do fundo sociocultural das línguas e culturas envolvidas na tradução, visto que essa não pode ser realizada sem considerar a situação comunicativa do TB e do TM. Nesse sentido, Reiss e Vermeer (1996) compreendem a língua como parte da cultura, sendo o meio convencional que uma comunidade cultural utiliza para pensar e se comunicar. Por sua vez, baseando-se no conceito de cultura de Göhring (1978), os autores afirmam que: "Entendemos por cultura o conjunto de normas e convenções vigentes em uma sociedade, bem como todos os comportamentos que essa dá lugar e os produtos resultantes de dito comportamento." (REISS; VERMEER, 1996, p. 20). Logo, para os autores, o tradutor deve ser bicultural, isto é, ter domínio de ambas as culturas envolvidas no processo tradutório. Sobre essa questão, Nord (1991, p. 11) afirma que: 
O domínio da cultura-fonte [pelo tradutor] deve permitirlhe reconstruir as possíveis reações em um receptor do texto-fonte $[. .$.$] , ao passo que o domínio da cultura de$ chegada lhe permite antecipar as possíveis reações de um receptor do texto traduzido, e então verificar a adequação funcional da tradução que produz. (tradução nossa) ${ }^{2}$

Ainda sobre os conceitos da Tradução Funcionalista, segundo Nord (1996), são pontos básicos o objetivo da tradução e a sua função na cultura meta. O objetivo comunicativo determinará o modo como se traduzirá o texto. Esse é definido pelo encargo de tradução, ou seja, pela situação comunicativa. Assim, a partir do reconhecimento de tal objetivo, é possível delimitar a função ou funções do TM na cultura meta, sendo o alcance dessa função, na recepção do TM que avaliará a funcionalidade da tradução e a sua adequação. Dessa forma, o contexto de recepção do TM é fundamental para a tradução. No entanto, na concepção da autora, a função de tal texto, ainda que possa diferenciar-se da(s) função(ões) do TB, não poderá ser incompatível com ela(s). Portanto, para alcançar a compatibilidade entre as funções dos textos, será preciso entender a função do TB para os seus receptores, para então, especificar a função que esse texto terá para os receptores do TM em sua situação-em-cultura.

Nord (1994, p. 101) explica que um texto não possui uma função comunicativa inerente, mas lhe é atribuída a partir da sua recepção por alguém, em uma situação específica, ativando suas experiências receptivas e convenções de funcionamento de certos gêneros textuais. Para a autora, o significado de um texto é constituído pela interdependência entre forma e conteúdo dos elementos textuais e a sua função ou funções comunicativas. Tais funções possuem a seguinte classificação: a) função fática: serve para estabelecer, manter ou terminar contato entre os participantes da comunicação; b) função referencial, informativa ou descritiva: se refere à representação, descrição de objetos ou fenômenos do mundo; c) função expressiva ou emotiva: trata-se da verbalização das emoções ou opiniões do emissor acerca de objetos ou fenômenos do mundo; d) função apelativa: pensada para conseguir um determinado

${ }^{2}$ Citação original: "His command of the source culture (SC) must enable him to reconstruct a ST recipient [...], whereas his command of the target culture (TC) allows him to anticipate the possible reactions of a TT recipient and thereby verify the functional adequacy of the translation he produces." (NORD, 1991, p.11). 
efeito extralinguístico nos seus interlocutores. Nesse sentido, traduzem-se funções comunicativas e não elementos estruturais isolados de um texto. Tais funções, na visão da autora, são transculturais, ainda que a forma de manifestação cultural dependa tanto do sistema linguístico quanto das normas e convenções específicas de cada cultura.

Nota-se que conhecer o objetivo e a função comunicativa da tradução é fundamental para essa teoria, entretanto, como proceder para identifica-los? Ambos estão interligados à situação de comunicação do TB e do TM. Na perspectiva de Reiss e Vermeer (1996), a translação requer uma dupla ação: 1. Analisar as condições de produção do TB ou texto de partida; e, 2. Analisar as condições de produção TM, isto é, o texto de chegada. Todavia, esses autores não conseguiram entrar em consenso sobre como seria esse modelo de análise envolvendo o TB e o TM de igual maneira. Sobre essa questão, Nord postula grande contribuição através de seu modelo de análise pré-translativo. Nas palavras da autora:

Empregando um modelo de análise exaustivo que considere os fatores intra e extratextuais, o tradutor estabelece a função-em-cultura de um texto base dado, para compará-la com a (pretendida) função-em-cultura de um texto meta encomendado, distinguindo os elementos (funcionais) do TB que podem ou devem se manter iguais no processo de tradução dos que terão que se adaptar às exigências da cultura meta. (NORD, 2012, p. 23, tradução nossa) $)^{3}$

Nord (2012, p.42) propõe responder às perguntas (Quem transmite? Para que e a quem? Através de que meio? Onde? Quando e porquê? Com qual função?) para identificar os aspectos extratextuais do TB e do TM, tais como, o autor/emissor, intenção, recepção, meio de transmissão, lugar, tempo e motivo. Além disso, ao buscar realizar as indagações (Sobre qual tema? Oferece qual informação? Pressupondo o que? Em que ordem? Usando quais elementos não-verbais? Quais

${ }^{3}$ Citação original: "Empleando un modelo analítico exhaustivo que considere los factores intra y extratextuales, el traductor establece la función-en-cultura de un texto base dado, para compararla con la (pretendida) función-en-cultura del texto meta encomendado, distinguiendo los elementos (funcionales) del TB que pueden o deben mantenerse iguales en el proceso de traducción de los que han de adaptarse a las exigencias de la cultura meta." (NORD, 2012, p. 23). 
palavras? Quais os tipos de frases? Em qual tom?), prioriza-se analisar a temática, o conteúdo, as informações pressupostas como conhecidas pelo destinatário, a ordem de composição ou organização do texto, os elementos não verbais, o tipo de léxico utilizado, a sintaxe e a prosódia ou entonação. Desse modo, a análise global desses elementos extra e intratextuais especificarão o efeito do texto. Para facilitar a aplicação desse modelo na Didática de Tradução, a autora esboça o seguinte quadro:

\section{QUADRO 1}

Modelo de análise pré-translativo de Nord (2012)

\begin{tabular}{|c|c|c|c|}
\hline & Perfil do texto base & Transferência & $\begin{array}{l}\text { Perfil do texto } \\
\text { meta }\end{array}$ \\
\hline \multicolumn{4}{|c|}{ Aspectos extratextuais } \\
\hline \multicolumn{4}{|l|}{ Emissor } \\
\hline \multicolumn{4}{|l|}{ Intenção } \\
\hline \multicolumn{4}{|l|}{ Receptor } \\
\hline \multicolumn{4}{|l|}{ Meio } \\
\hline \multicolumn{4}{|l|}{ Lugar } \\
\hline \multicolumn{4}{|l|}{ Tempo } \\
\hline \multicolumn{4}{|l|}{ Motivo } \\
\hline \multicolumn{4}{|l|}{ Função } \\
\hline \multicolumn{4}{|c|}{ Aspectos intratextuais } \\
\hline \multicolumn{4}{|l|}{ Tema } \\
\hline \multicolumn{4}{|l|}{ Conteúdo } \\
\hline \multicolumn{4}{|l|}{ Pressuposições } \\
\hline \multicolumn{4}{|l|}{ Composição } \\
\hline \multicolumn{4}{|l|}{$\begin{array}{l}\text { Elementos não } \\
\text { verbais }\end{array}$} \\
\hline \multicolumn{4}{|l|}{ Léxico } \\
\hline \multicolumn{4}{|l|}{ Sintaxe } \\
\hline \multicolumn{4}{|l|}{ Suprassegmentais } \\
\hline \multicolumn{4}{|c|}{ Efeito comunicativo } \\
\hline Efeito & & & \\
\hline
\end{tabular}

Fonte: Nord (2012, p. 155).

Primeiramente, pode-se preencher a coluna direita com base nas informações do encargo de tradução (situação comunicativa meta) e depois se analisa o TB, preenchendo a coluna à esquerda. Se o encargo 
de tradução exige um TM com função idêntica ou equivalente ao TB, começa-se preenchendo a coluna esquerda com uma análise exaustiva do TB, e, depois, apontam-se os dados correspondentes para cada um dos fatores na coluna direita. No primeiro caso, Nord (2012, p. 156) explica que se as duas colunas forem respondidas, com base nas perguntas básicas apontadas pela autora, o contraste entre ambas mostrará quais são os fatores idênticos ou diferentes nas duas situações comunicativas. No segundo caso, o contraste entre as colunas mostrará com clareza os problemas de tradução, os quais serão especificados na coluna do meio, junto com os procedimentos que conduzem a uma solução adequada e funcional.

Em relação à aplicação desse modelo para o ensino de tradução, Nord (1996) salienta que é necessário seguir três princípios, a saber: o princípio da transparência, o princípio da autenticidade e o princípio da comunicabilidade. O primeiro significa que o docente deve deixar claro para os aprendizes as suas expectativas sobre a qualidade do TM, mediante um encargo de tradução detalhado. O segundo princípio consiste em escolher atividades de tradução de textos autênticos, reais e que tenham relevância para a prática profissional. Por sua vez, o terceiro princípio requer que os textos se apresentem em sua situação comunicativa ou em uma forma que se aproxime da situação que funciona ou que funcionou originalmente. A autora afirma que, visando cumprir o princípio da transparência, o encargo de tradução deve conter as seguintes informações sobre a situação meta: 1. A função ou funções comunicativas que o TM deve alcançar; 2. Os destinatários do TM; 3. As condições temporais e locais previstas para a recepção do TM; 4. O meio pelo qual será transmitido o TM; 5. O motivo pelo qual se produz o texto; as quais implicarão nas escolhas intratextuais do TM. Em consonância com o contexto de formação de futuros tradutores, Nord (2009, p. 232) pondera que o encargo de tradução nem sempre tem que ser totalmente realista, pois, às vezes, um encargo de tradução didático é necessário para abordar um determinado problema de tradução ou para excluir certos problemas que não foram estudados ainda.

Ao propor uma atividade com o uso da tradução, é essencial que se reflita sobre como avaliar as traduções dos aprendizes, já que os critérios avaliativos deverão ser esclarecidos aos estudantes. Nord (1996) especifica que se o processo tradutório é guiado por um encargo de tradução, assim, será também esse que servirá para avaliá-la, isto 
é, um não cumprimento de tal encargo, no que diz respeito a aspectos funcionais, deve ser considerado como erro ou falta na tradução.

Nord (1996), no âmbito da Didática de Tradução, categoriza os seguintes erros de tradução de forma hierárquica: erros pragmáticos, erros culturais e erros linguísticos. Os erros pragmáticos prejudicam o objetivo ou função do texto meta ao desrespeitar as instruções pragmáticas do encargo de tradução. Por meio desse tipo de erro, ou o leitor obtém uma informação equivocada ou se omite alguma informação essencial do TB, no TM, prejudicando a sua função. A título de ilustração, a autora apresenta a tradução de um folheto informativo, do alemão para a língua espanhola, sobre o sexto centenário da universidade alemã de Heidelberg, em que, na versão espanhola, omite-se a data dos festejos, prejudicando a função informativa do TM. Por sua vez, os erros culturais comprometem, de forma indireta, a função do texto meta, ao não cumprir às normas e/ou convenções gerais ou genéricas da cultura meta, no tocante a aspectos estilísticos, de formato, de cortesia, convenções de pesos e medidas, etc. Esse tipo de erro dificulta, mas não impossibilita a compreensão do TM, seria o caso, por exemplo, de traduzir uma entrevista com o rei da Espanha para o português, utilizando um pronome de tratamento informal ou pouco cortês entre o entrevistador e o entrevistado. Por último, os erros linguísticos são as faltas gramaticais, lexicais, ortografia, pontuação, estrutura sintática inadequada etc. Dessa maneira, o TM será avaliado não por sua "equivalência" com o TB, no sentido formalista do termo, mas por sua adequação ao encargo de tradução (funcionalidade) e lealdade aos agentes envolvidos na tradução, ou seja, o autor do TB, o receptor do TM, o iniciador da tradução e o tradutor (NORD, 2009, p. 219).

Outra questão relevante para a Didática de Tradução Funcionalista se refere às dificuldades e aos problemas de tradução, os quais, conforme Nord (2009), diferenciam-se, uma vez que as dificuldades de tradução são individuais e surgem durante o processo tradutório, sendo necessário, superá-las com instrumentos adequados. Já os problemas de tradução são gerais e devem ser solucionados mediante procedimentos translativos próprios da competência tradutória. Sobre as dificuldades de tradução, a autora enumera as seguintes: 1. Dificuldades textuais - referentes à incompreensão e falha no processamento de textos devido à complexidade do léxico, sintaxe, usos verbais, incoerência, má qualidade da reprodução do texto, etc.; 2. Dificuldades de competência - relacionadas com a incompatibilidade entre a tarefa de tradução e a competência translativa 
do tradutor, por exemplo, conhecimentos insuficientes sobre as línguas e culturas envolvidas na tradução ou a falta de conhecimento sobre o tema e terminologia específica utilizada no TB; 3. Dificuldades profissionais - são aquelas derivadas da ausência, imprecisão ou complexidade do encargo de tradução, por exemplo, pouca clareza da função do TM e dificuldades ou impossibilidade de comunicação entre o tradutor e o cliente; 4. Dificuldades técnicas - estão relacionadas às condições de trabalho do tradutor, tais como a falta de materiais de pesquisa adequados (dicionários, acesso à internet ou base de dados) e pouco prazo para a realização da tradução.

No que tange aos problemas de tradução, Nord (2009, p. 234) pontua que estão relacionados com os erros de tradução e podem ser divididos em: 1. Problemas pragmáticos de tradução, que interferem na compreensão da intenção comunicativa do TM; 2. Problemas culturais de tradução, que se centram no respeito às convenções culturais envolvidas na tradução; 3. Problemas linguísticos de tradução, relacionados com a falta de conhecimento linguístico adequado para realizar as correspondências necessárias na hora de traduzir; 4. Problemas de tradução extraordinários, são geralmente encontrados em textos literários e as soluções para resolvê-los não poderão ser utilizadas de forma generalizada para outros textos. O aprendiz pode se deparar com um ou todos, desse modo, o professor deve ser criterioso na seleção dos textos que serão utilizados para a tradução.

Nord (2012, p. 161) orienta, também, que nas aulas de formação de tradutores, tendo em vista a grande variedade de temas didáticos (tais como desenvolver competências linguísticas, linguístico-culturais, translativas, etc.), é necessário estruturar e sistematizar as aulas, indo além da categorização entre a tradução de textos especializados ou de textos gerais. A autora sugere que os fatores do modelo de análise pré-translativo podem servir como ponto de partida para a sistematização dos problemas de tradução com as suas soluções e, ainda, para a seleção de materiais didáticos adequados às aulas de tradução. Assim, para a seleção de textos autênticos, nem sempre de curta extensão, a autora orienta que, quando necessário, faça-se um recorte do texto, mas que seja acompanhado de um resumo da obra completa. Se o texto parece complexo ao nível dos alunos, pode-se facilitar a atividade a partir de um encargo de tradução mais simples. Também, os textos podem ser classificados e selecionados, considerando-se os seus aspectos extratextuais (emissores, receptores, 
intenções, etc.) ou intratextuais (tema, léxico, sintaxe, etc.) e, ainda, seguindo uma progressão didática por meio de níveis de dificuldades.

À guisa de conclusão, mediante o exposto, nota-se que a análise textual, incluindo os contextos de produção e recepção, tem papel central para a Tradução Funcionalista. Além disso, vale reiterar que, em um texto, pode-se encontrar um ou vários problemas de tradução, logo, por meio de uma sequência didática (doravante SD) com a tradução de gêneros textuais autênticos, os problemas e/ou dificuldades encontrados pelo futuro tradutor poderiam ser abordados, de forma detalhada, através dos módulos previstos na SD. Portanto, com base nesta proposta, propor-se-á a elaboração de SD aplicadas ao ensino de tradução.

\section{A elaboração de SD aplicadas ao Ensino de Tradução}

Reconhecer o gênero textual permite ao tradutor antecipar características intratextuais típicas do TB, além disso, se as informações extratextuais de um TB são escassas, através do gênero, é possível ter uma base para interpretar a sua funcionalidade. (NORD, 2012). Dessa forma, identificar o gênero textual do TB pode ter impacto tanto na recepção quanto na produção do TM, além de auxiliar no reconhecimento da intenção do seu autor, visto que há textos que são utilizados em situações padronizadas, sempre para as mesmas funções (meteorológico, oração, manual de instrução), e essas situações resultam em determinada convenção sobre as intenções do emissor ou autor do texto, para além do tipo de receptor. A partir dessa perspectiva, verifica-se que o texto não pode ser compreendido em sua totalidade se isolado de sua situação ou prática comunicativa. Portanto, mais do que lidar com sequências linguísticas ou composicionais (aspectos lexicais, sintáticos, etc.), o tradutor lida com gêneros textuais, nas palavras de Marcuschi:

Usamos a expressão gênero textual como uma noção propositalmente vaga para referir os textos materializados que encontramos em nossa vida diária e que apresentam características sociocomunicativas definidas por conteúdos, propriedades funcionais, estilo e composição característica. Se os tipos textuais são apenas meia dúzia, os gêneros são inúmeros. (MARCUSCHI, 2010, p. 23) 
O autor chama atenção para a diferença entre os termos tipo textual e gênero textual, já que, em muitos materiais de ensino, há confusão no emprego desses termos. O primeiro constitui uma espécie de sequência teoricamente definida pela natureza linguística de sua composição (aspectos lexicais, sintáticos, tempos verbais) e as categorias mais conhecidas são: narração, argumentação, exposição, descrição e injunção. O segundo termo se refere a ações linguageiras materializadas em textos. Nesse sentido, para a noção de gênero textual, predominam os critérios de ação prática, circulação sócio-histórica, funcionalidade, conteúdo temático, estilo e composicionalidade. Assim, em um gênero textual, realizam-se um ou vários tipos textuais, caracterizados por uma heterogeneidade tipológica. Por exemplo, no gênero textual peça teatral, há sequências tipológicas descritivas e expositivas (ao apresentar as personagens ou descrever o ambiente das cenas), argumentativas (no diálogo entre as personagens) ou injuntiva (ao ordenar), entre outros.

Apresentados tais termos, é importante explicitar o que Demétrio (2014, p.66) afirma sobre o processo tradutório e o conhecimento sobre gêneros textuais. A autora concebe o processo tradutório como uma retextualização, assim como Travaglia (2013). Portanto, considera que o tradutor executa movimentos que se assemelham aos de um produtor/ escritor de um texto. Nesse viés, Demétrio (2014) explica que o modelo de análise pré-tradutório de Nord (2012) pode contemplar todos os elementos de textualidade propostos por Beaugrande e Dressler (1981) e Cassany (2010), tais como: intencionalidade, aceitabilidade, intertextualidade, informatividade, coerência, coesão, adequação e correção gramatical.

Em consonância com essa concepção, pressupõe-se que, ao elaborar uma tradução, produz-se um texto e se empreende uma prática de linguagem por meio de um determinado gênero textual. Portanto, é viável aliar a atividade tradutória ao dispositivo de sequências didáticas para o desenvolvimento de práticas de linguagem e domínio de gêneros textuais, na formação de tradutores.

Ao pensar em formas didáticas de se abordar os gêneros textuais em sala de aula, pesquisadores do chamado Grupo de Genebra, tais como Dolz e Schneuwly (1998), elaboraram uma proposta de transposição didática do gênero baseada na construção, sistematização e aplicação de sequências didáticas (SD). Essas são [...] um conjunto de atividades escolares organizadas, de maneira sistemática, em torno de um gênero textual oral ou escrito." (DOLZ; NOVERRAZ; SCHNEUWLY, 
2004, p. 96). Para os autores, quando os usuários de uma língua se comunicam, adaptam-se à situação comunicativa e, quando interagem em situações parecidas, escrevem/falam textos com características semelhantes, os quais são considerados gêneros textuais, "conhecidos de e reconhecidos por todos, e que, por isso, facilitam a comunicação." (DOLZ; NOVERRAZ; SCHNEUWLY, 2004, p. 97). Partindo dessa premissa, aludem que uma SD se centra em possibilitar o domínio de um gênero textual, permitindo ao aprendiz que escreva ou fale de uma maneira mais adequada, numa dada situação comunicativa.

No que se refere ao procedimento de uma SD, Barros (2014, p. 154) postula que, sinteticamente, ela está constituída por cinco etapas, as quais ilustramos a seguir:

FIGURA 1 - Descrição do procedimento de uma SD com base em Barros (2014)

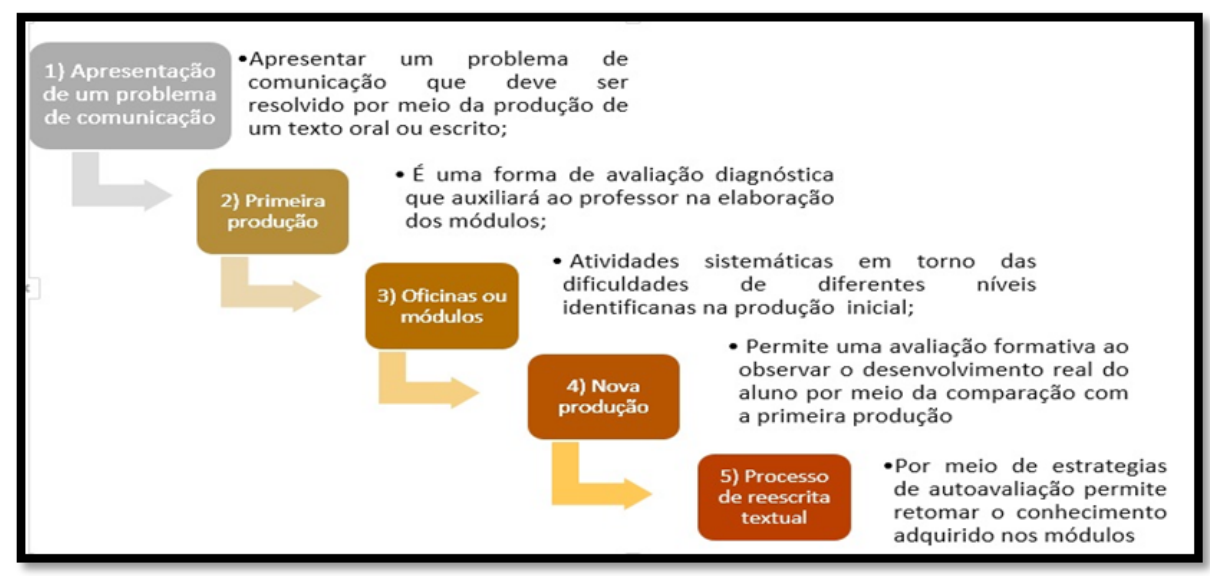

Fonte: Adaptado de Barros (2014).

Através da Figura 1, verifica-se que uma SD se inicia com a apresentação de uma situação ou problema de comunicação, na qual é feita uma contextualização da prática de linguagem a ser empreendida e há a exposição da motivação para a produção de um gênero textual. No caso de uma SD com a tradução funcionalista, a etapa de apresentação da situação inicial corresponderá a amostras de traduções do gênero determinado que circulam socialmente, além da apresentação de um texto a ser traduzido e um encargo de tradução didático. Conforme Nord (1996), o encargo de tradução deve especificar a função ou funções comunicativas 
que a tradução deve alcançar, além de determinar os receptores do TM, as condições temporais e espaciais previstas para a recepção da tradução, o meio pelo qual será transmitida e o propósito da tradução.

Em relação à fase de apresentação da situação comunicativa, Laiño (2014, p. 99), ao realizar uma SD com a tradução funcionalista, não define todos os aspectos de um encargo de tradução didático, mas propõe a elaboração de um projeto de tradução a ser desenvolvido individualmente pelos aprendizes, apenas definindo a nacionalidade do público meta (brasileiro) e do TB (publicidades argentinas). Assim, os estudantes puderam refletir sobre o que podiam manter, mudar e/ou adaptar, analisando o receptor do TM, o produtor do TB, devendo estar conscientes e determinar todos os aspectos que definem o processo tradutório para realizar as ações de forma segura. A autora relaciona esse processo de especificação do projeto de tradução à etapa de planejamento da escrita, proposta por Cassany (2010), visto que ambos ocorrem antes da elaboração do texto.

A partir dessa primeira etapa, inicia-se a produção inicial, a qual será vista pelo professor-pesquisador como um diagnóstico acerca do domínio do gênero textual pelos alunos e de suas capacidades de linguagem (BARROS, 2012, p. 82). A produção inicial, na SD com a tradução funcionalista, será baseada em uma análise do TB a partir do modelo de análise pré-tradutório de Nord (2012), o qual permite analisar as características intra e extratextuais do TB e do TM, mediante um encargo de tradução determinado, ou, ainda, um projeto de tradução como realizou Laiño (2014). Esse modelo de análise possibilitará ao aprendiz pesar os elementos que devem ser adaptados à cultura do receptor do TM e, com essas informações, poderá produzir uma primeira produção do TM. A etapa da análise pré-tradutória de Nord (2012), antes da primeira produção, coincide com o que Costa-Hürbes e Simioni (2014, p. 26) chamam de Módulo de Reconhecimento, uma adaptação do esquema de SD suíço à vertente brasileira. Nessa etapa, as autoras definem que é feita uma pesquisa, leitura e análise linguística do gênero a ser produzido, aspectos proporcionados pelo modelo de análise de Nord (2012).

Com base nas dificuldades apresentadas pelos alunos, ao realizarem a primeira produção do gênero textual em uma SD, são elaborados os módulos. Esses, segundo Cristóvão (2009, p.310), dependem das capacidades dos alunos, do nível escolar, do currículo e do gênero trabalhado. Não há uma quantidade limite de módulos que possam 
ser realizados em uma SD, podendo variar de acordo com o contexto de ensino, disponibilidade de tempo, objetivos da SD, etc. Na visão de Barros (2012, p.82), os módulos devem abordar problemas de diferentes níveis (apresentação da situação de comunicação, aprofundamento temático, infraestrutura do gênero, etc.), além de atividades e exercícios variados, desde atividades de observação e análise de textos a atividades de leitura, oralidade, audição, etc. Também, pode-se intercalar atividades com outros gêneros, e, ao fim de cada módulo realizado, a autora sugere a elaboração de listas de constatações do que foi aprendido.

De acordo com a evolução dos módulos, para Mosquera Roa e Sanchez Abchi (2015, p. 208), a SD pode ser classificada em: (i) sequências de progressão linear ascendente: a progressão dos módulos da SD parte do simples para o complexo, por exemplo, abordando primeiro aspectos linguísticos para depois abordar questões de textualização; (ii) sequência com progressão estável: abordam temas do funcionamento linguístico em todos os módulos visando melhorar a produção final; (iii) sequências com alternâncias nos níveis de trabalho com os módulos: são sequências que abordam, inicialmente, partes específicas do texto, logo, questões estruturais e organizacionais, para chegar aos aspectos formais; (iv) sequências de progressão linear descendente: são aquelas SD que, já nos primeiros módulos, abordam questões mais complexas de planejamento ou de coesão textual, para depois explorar o funcionamento linguístico (sintaxe, léxico, ortografia, etc.).

No caso dos módulos de uma SD com o uso da tradução funcionalista, esses serão baseados nas dificuldades apresentadas pelos aprendizes durante a análise textual pré-tradutória de Nord (2012) e na primeira produção do TM. Assim, se, por exemplo, os aprendizes mostrarem dificuldades no que tange à identificação da composicionalidade do TB e TM, elaborar-se-ão módulos específicos sobre o gênero textual que está sendo traduzido. Ou, ainda, se os aprendizes mostrarem dificuldades na adequação linguística do TM ao público meta do encargo de tradução, planejar-se-ão módulos específicos acerca dos aspectos linguístico-culturais relacionados à adequação. Por sua vez, poderá haver módulos específicos para os problemas de tradução, identificados na análise pré-tradutória de Nord (2012).

Após a execução dos módulos, propor-se-á a reescrita da primeira produção, a qual, nas palavras de Cristóvão (2009, p. 311): "se caracteriza como o lugar de integração dos saberes construídos e de instrumentos 
apropriados". Essa nova produção, no tocante ao trabalho do professor, pode ser comparada à primeira produção, o que permitirá ao professor uma avaliação do desenvolvimento real do aluno e uma avaliação formativa (BARROS, 2012, p. 82). Logo, no tocante à SD com o uso da tradução funcionalista, será proposta uma reescrita da primeira produção do TM, que constituirá a versão final. Espera-se que tal produção seja funcional na situação-em-cultura, determinada no encargo de tradução didático, proposto para a SD. Na prática de uma SD: "O aluno deve aprender que escrever é (também) reescrever. A estruturação da SD em primeira produção, por um lado, e produção final, por outro, permite tal aprendizagem.” (DOLZ; NOVERRAZ; SCHNEUWLY, 2004, p.113). Diante desse contexto, é possível realizar uma SD com o uso da tradução funcionalista, já que no processo tradutório circular, exposto por Nord (2012), o tradutor/aprendiz está frequentemente analisando o TB, verificando as condições de produção do TM, durante a sua elaboração. Por conta disso, para alcançar um TM funcional ao seu encargo de tradução, poderá escrever várias versões preliminares do TM.

Também, no procedimento da SD, conforme Barros (2012, p. 82), mesmo a nova produção ou produção final poderá passar por um último processo de revisão ou reescrita antes de sua circulação social. Segundo Costa-Hürbes e Simione (2014, p. 27), nessa etapa de circulação, o texto produzido será compartilhado com seus interlocutores, conforme previsto inicialmente na apresentação da situação comunicativa, em nosso caso, no encargo de tradução. Tal etapa poderá contribuir para o alcance do princípio da comunicabilidade, já explicitado na seção anterior, no que se refere aos princípios de elaboração das atividades de tradução funcional proposto por Nord (1996).

Por outro lado, ao estar centrada na apropriação do gênero textual, a SD parte de um modelo didático de gênero, isto é, o reconhecimento dos elementos ensináveis de um determinado gênero textual que guiará a elaboração da SD. O modelo contempla, na concepção de Pietro e Schneuwly (2014, p. 58), a definição geral do gênero, os parâmetros do contexto comunicativo, os conteúdos específicos a estrutura global, as operações linguageiras e as suas marcas linguísticas. Para obter tais informações, segundo os autores, é necessário reunir dados sobre: 1. As práticas sociais de referências, ou seja, o contexto de produção do gênero; 2. A literatura a respeito do gênero; tanto de aspectos psicológicos e funcionamento dos discursos quanto no que se refere ao ensino 
do gênero; 3. As práticas de linguagem dos alunos; e, 4. As práticas escolares. Os autores asseveram que o modelo didático de gênero é operacionalizado numa SD sob três modalidades diferentes, a saber: auxiliar a elaboração da situação de produção do texto; especificar os objetivos de aprendizagem dos diferentes módulos da SD e o subsidiar as tarefas propostas aos alunos para o alcance de tais objetivos.

No que toca à construção do modelo didático de gênero, Dolz e Schneuwly (1998) ponderam que se deve respeitar os princípios de: 1. Pertinência, considerando as finalidades e os objetivos escolares em função das capacidades dos alunos; 2. Legitimidade, utilizando os conhecimentos de experts; e 3. Solidarização, integrando as diferentes dimensões que constituem o gênero. É oportuno esclarecer que a modelização do gênero pode subsidiar tanto a elaboração de SD quanto a elaboração de outros materiais didáticos centrados no gênero textual. Nesse âmbito, Barros (2012, p. 161) propõe um dispositivo didático de modelização para qualquer gênero textual a fim de facilitar a transposição didática. A proposta deste artigo basear-se-á neste dispositivo para elaborar o modelo didático do gênero peça teatral de comédia, que será apresentado na próxima seção.

Por meio de uma SD busca-se desenvolver as capacidades de linguagem, pois é através delas que o indivíduo realiza uma prática de linguagem, ou seja, mediações comunicativas, cristalizadas em forma de gêneros textuais (PINTO, 2010, p. 53). Logo, as capacidades de linguagem são os conhecimentos necessários para a produção e a compreensão de um gênero textual em uma determinada situação comunicativa. Essas capacidades, de acordo com Dolz, Noverraz e Schneuwly (2004), podem ser subdivididas em:

1. Capacidades de ação, que dizem respeito ao contexto de produção da ação de linguagem e a sua adequação ao ambiente físico, social e subjetivo. Conforme Stutz e Cristóvão (2011, p. 576), essas capacidades possibilitam: (1CA) Realizar inferências sobre quem escreve o texto, para quem ele é dirigido, sobre qual assunto, quando o texto foi produzido, onde foi produzido e para que objetivo; (2CA) Avaliar a adequação de um texto à situação na qual se processa a comunicação; (3CA) Levar em conta propriedades linguageiras na sua relação com aspectos sociais e/ou culturais; (4CA) Mobilizar conhecimentos de mundo para compreensão e/ou produção de um texto. 
2. Capacidades discursivas, as quais se relacionam com as escolhas no nível discursivo e a infraestrutura geral do texto, plano geral, tipos de discurso e sequências. Essas, na visão de Stutz e Cristóvão (2011, p. 577), permitem: (1CD) Reconhecer a organização do texto, como layout, linguagem não verbal (fotos, gráficos, títulos, formato do texto, localização de informação específica no texto) etc.; (2CD) Mobilizar mundos discursivos para engendrar o planejamento geral do conteúdo temático; (3CD) Entender a função da organização do conteúdo naquele texto; (4CD) Perceber a diferença entre formas de organização diversas dos conteúdos mobilizados.

3. Capacidades linguístico-discursivas, que tratam dos mecanismos de textualização, operações de conexão e segmentação, coesão nominal e verbal, mecanismos enunciativos (gerenciamento de vozes e modalizações), construção de palavras e enunciados e escolhas lexicais. Tal capacidade, nas palavras de Stutz e Cristóvão (2011, p. 577) proporcionam a construção de sentido mediante representações sobre as operações de textualização, de construção de enunciados e da escolha do vocabulário. Os conhecimentos a serem abordados se referem à microestrutura (as unidades linguísticas das frases e sentenças) como: coesão, conexão verbal, etc.

Ao descrever essas capacidades de linguagem, verifica-se que as mesmas podem ser contempladas e integradas ao utilizar o modelo de análise pré-translativo de Nord (2012), como ilustramos na Figura 2. Fato que corrobora à proposta de aliar o procedimento de sequências didáticas com a tradução funcionalista de gêneros textuais autênticos para a formação de tradutores. 
FIGURA 2 - As capacidades de linguagem dentro do modelo de análise textual pré-tradutório de Nord (2012)

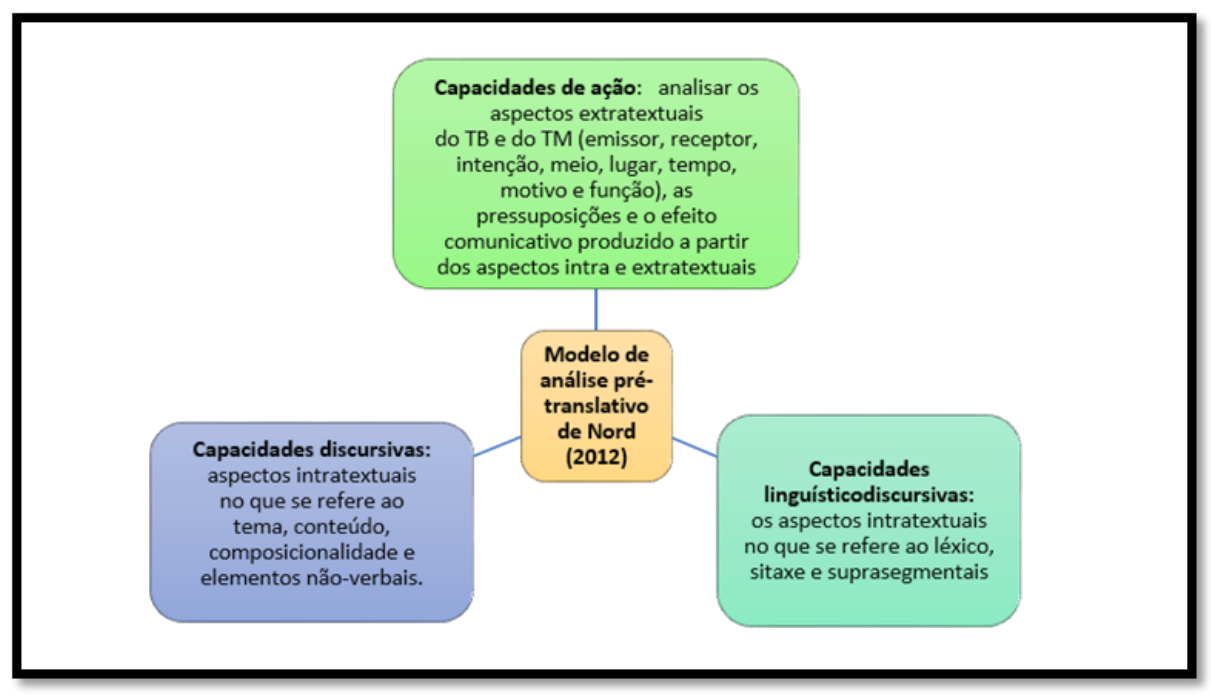

Fonte: Autoria própria.

Diante do exposto, reitera-se que, ao realizar uma SD no viés aqui proposto, o modelo de análise pré-translativo de Nord (2012) proporcionará ao docente um diagnóstico inicial das dificuldades dos aprendizes e dos problemas de tradução, complementar à primeira produção. Além de permitir observar, juntamente com a produção inicial, quais capacidades de linguagem devem ser mais abordadas com vistas à apropriação do gênero textual da SD. Entretanto, é pertinente salientar que uma SD é sempre construída ou adaptada a partir de seu contexto de ensino-aprendizagem, pois, como afirma Barros (2014, p. 155), ela não é um manual didático, mas um planejamento de atividades sistematizadas com foco na apropriação de um gênero. Assim, na concepção da autora, mesmo que o professor encontre SD prontas, ele terá que pesquisar sobre o gênero que vai abordar, a prática social que esse gênero se insere, a esfera social de comunicação, o nível das capacidades de linguagem dos alunos em relação ao gênero, etc. Uma vez que a aplicação de uma SD desenvolvida previamente, isto é, sem considerar o contexto de ensino e as capacidades de linguagem dos aprendizes, a reduziria a planos de aulas ou projetos didáticos. Feita essa ressalva, a seguir, pretende-se ilustrar 
um projeto inicial de SD com a tradução do gênero peça teatral, para a formação de tradutores.

\section{Proposta de SD a partir da tradução funcional do gênero textual peça de teatro}

A proposta aqui reportada faz parte de uma pesquisa em andamento. Portanto, não serão apresentados resultados e módulos prontos da SD. Objetiva-se, no entanto, ilustrar o modelo didático de gênero da SD, exemplificar a definição de um encargo de tradução ou apresentação da situação comunicativa, além de sugerir critérios para seleção de textos que podem variar a depender do contexto de ensino-aprendizagem.

O modelo didático de gênero auxilia na identificação das características ensináveis do gênero textual escolhido para ser estudado. Explicitar-se-á o modelo didático do gênero peça teatral a partir das orientações de Cristóvão (2010) e Barros (2012). Incialmente, Cristóvão (2010) afirma que é necessário um "levantamento do perfil da situação de ensino que fundamente e oriente nossas escolhas dos elementos a serem ensinados no contexto em que nos inserimos" (CRISTÓVÃO, 2010, p. 103). Tal contexto, nesse caso, trata-se da disciplina "Introdução aos Estudos da Tradução em Língua Espanhola", ofertada no $2^{\circ}$ semestre do Curso de Letras, de uma universidade pública brasileira. Assim, recorrese, além do programa da disciplina, ao Projeto Político Pedagógico do referido curso, a fim de averiguar quais capacidades o aluno deve desenvolver ao longo de sua graduação. Dentre elas, destacam-se as seguintes, pela possibilidade de serem abordadas na disciplina:

- Domínio de conceitos que permitam a produção de textos em Espanhol, considerando diferentes gêneros e registros linguísticos;

- Capacidade para atuar como mediador em contextos interculturais; [..]

- Capacidade de aplicar o conhecimento da Língua Espanhola em traduções e versões, bem como a análise e compreensão de processos tradutórios; [...].

(Projeto Político Pedagógico do Curso Letras Língua Espanhola e suas Literaturas, 2009, p. 27-29) 
Essas capacidades podem fazer parte do objetivo da SD, uma vez que o PPP é um documento oficial norteador do contexto de ensino. Nesse caso, levando-se em conta o programa da disciplina, que visa discorrer sobre o processo tradutório, técnicas, problemas e prática de tradução, pode-se elencar os seguintes objetivos para a SD, a partir da tradução funcional: apropriar-se do gênero textual peça de teatro; empreender um processo tradutório; mediar diferenças culturais na tradução. A escolha do gênero peça teatral se justifica pelo fato de ser um gênero literário nem sempre habitual aos estudantes, além de apresentar diferentes registros linguísticos, predomínio de texto dialogal e possibilitar a abordagem de problemas de tradução variados.

Ainda, mediante os procedimentos para a elaboração de um modelo didático, segundo Cristóvão (2010, p.108): "recorremos à literatura pertinente de diferentes áreas, tanto à que é produzida por especialistas nesse gênero quanto à de pesquisadores do discurso". Desse modo, esta pesquisa apoiar-se-á em Uberfeld (2005) e Ryngaert (1995) em relação às características do gênero peça de teatro, além de Romão (2010b) acerca da tradução teatral. É importante destacar que o teatro é a um só tempo produção literária e representação concreta, assim, deve-se ter em mente se, na SD, ambos aspectos serão abordados. Nesse gênero, há uma relação complexa entre a oralidade e a escrita, fato que pode ser explorado, posto que Marcuschi (2010, p.35) cita a pertinência de se ter em mente a relação entre o oral e o escrito, no contexto dos gêneros textuais. Sobre a constituição desse gênero textual, de acordo com Ubersfeld (2005) e Ryngaert (1995), há uma organização tipográfica própria, na qual há dois grandes elementos: a didascália (ou rubrica) e o diálogo.

A didascália consiste nas partes do texto que não se destinam a ser pronunciadas no palco, mas que ajudam ao leitor compreender e imaginar o espaço em que ocorrem as cenas e as ações das personagens. Ela descreve o contexto de comunicação e é identificada por marcas tipográficas específicas, tais como parênteses, colchetes ou letras itálicas e/ou maiúsculas. Fazem parte da didascália: o nome das personagens (em lista inicial e no decorrer dos diálogos); as indicações cênicas ao longo dos diálogos; a descrição das cenas no início de atos, quadros, cenas ou fragmentos. A seu turno, o diálogo é constituído pelas falas das personagens, podendo encadear-se de modo cerrado (princípio das falas alternadas) ou manifestar uma evidente desigualdade na extensão dos discursos. Logo, os grandes "blocos" de textos assinalam as tiradas, ou seja, os longos discursos de uma personagem sem a interrupção de outras 
personagens, isto é, monólogos. (RYNGAERT, 1995, p. 43). A fala das personagens, no texto, pode se apresentar em verso ou em prosa. Além disso, Ubersfeld (2005, p. 7) chama a atenção sobre a distinção linguística entre a didascália e o diálogo que, para a autora, está relacionada com a enunciação, sendo, portanto, na didascália a fala do autor e no diálogo a fala das personagens. Já o discurso, no teatro, está centrado na enunciação, é um discurso do eu/tu e do aqui/agora (UBERSFELD, 2005, p.175).

Ryngaert (1995) afirma que a maioria das peças teatrais está organizada em diferentes partes e o seu modo de organização remete a uma determinada estética. Tradicionalmente, há os atos e cenas, os quais, nas tragédias se distribuíam em cinco atos e nas comédias em três atos. Os atos podem ser divididos em cenas, de acordo com a entrada e a saída de personagens, e as cenas podem ser divididas em quadros, a partir de uma concepção pictórica de atmosferas diferenciadas das cenas. Na prática moderna, o autor ressalta que inspirados nos cinemas, os autores teatrais falam de sequências, fragmentos, movimentos (em referência às obras musicais) e pedaços, jornadas e partes que, às vezes, possuem títulos próprios. (RYNGAERT, 1995, p. 38). Essa divisão, também, implica na decupagem, isto é, na forma de apreender o real. Ela organiza as ações e dá ritmo ao texto.

Uma peça teatral é considerada obra literária e de ficção. Por esse motivo, apresenta componentes narrativos, a saber: o enredo, o espaço, o tempo e as personagens. Tradicionalmente, a narrativa, na peça teatral, pode constituir-se por: uma exposição (compreensão da ação, personagens e assunto); um nó (obstáculos e contrariedades na ação, constituindo conflitos, peripécias) e desfecho (a eliminação dos obstáculos e problemas desenvolvidos nos acontecimentos). O enredo, em uma peça teatral, é construído através de ações realizadas pelas personagens; o tempo e o espaço são expressos tanto nas didascálias quanto nos diálogos, por meio de marcadores temporais, advérbios de lugar, etc. Depreende-se, assim, que as personagens têm papel fundamental no texto teatral, visto que é por meio de suas falas e ações que o enredo se desenvolve. Ubersfeld (2005, p.174) esclarece que toda personagem, no teatro, busca reproduzir a linguagem da classe social a que pertence, embora não a reproduza com exatidão referencial. A autora explica que o idioleto das personagens, geralmente, ao utilizar particularidades linguísticas (representações da língua popular), busca caracterizar aquele que está fora do grupo, provocando o riso, ao representar, por exemplo, personagens estrangeiras ou populares que não sabem utilizar a língua das personagens cultas. 
Por outro lado, acerca da tradução desse gênero textual, Romão (2010b, p. 54) aponta que, ao receber um texto teatral para ser traduzido, deve-se inquirir ao iniciador da tradução sobre o fim a que se destina o texto (representação, adaptação, texto literário), pois em torno disto gravitará muitas das decisões do tradutor. Romão (2010b, p. 55), também, expõe algumas especificidades da tradução teatral, com base em sua experiência, ao traduzir três peças alemãs para o Português Brasileiro, a partir do modelo de Tradução Funcionalista. Ele afirma que, para traduzir, baseou-se nos seguintes nortes: a) a tradução seria feira a partir de um contexto linguístico e cultural para outro contexto linguístico e cultural diferente; b) tratava-se do gênero textual peça teatral; c) este gênero está inserido na tipologia literária, mas, também, na tipologia audiomedial, isto é, corresponde a textos destinados à apresentação pública; d) os textos estariam sujeitos a sofrer alterações, caso viessem a ser encenados; e) os textos deixariam sua função de texto alemão para público alemão e passariam a funcionar na situação linguístico-cultural brasileira.

Além disso, Romão (2010b) explana que um dos fatos mais complexos, ao traduzir o gênero peça teatral, consiste em lidar com a ilusão teatral. Pois, não raro, o tradutor se deparará com fatos irreais que deverão ser apresentados de forma convincentemente real, ou, pelo contrário, poderá lidar com situações reais, mas não fazer uso de uma linguagem documentária e informativa, devido a uma das funções do texto teatral, isto é, a sua dimensão literária. Assim, o autor elenca as seguintes dificuldades encontradas na tradução das peças teatrais, empreendida por ele: 1. Tradução de contexto cultura regional específico; 2. Perícia na tradução de rubricas (didascálias); 3. Formalismos linguísticos relacionados com a época das obras, tais como, as formas de tratamentos; 4. A mescla de diferentes tipos textuais na peça teatral (expressivo-literário e informativo); 5. Tradução de nomes de personagens e topônimos.

Para concluir o modelo didático do gênero peça teatral, Cristóvão (2010) sugere recolher um corpus de 10 peças teatrais para análise, assim recolhemos cinco peças teatrais brasileiras e cinco hispânicas ${ }^{4}$,

\footnotetext{
${ }^{4}$ Peças brasileiras analisadas: "O demônio familiar" (José de Alencar, 1857, Ceará); "O badejo" (Artur de Azevedo, 1898, Maranhão); "Caiu o Ministério" (França Júnior, 1882, Rio de Janeiro); "Quem desdenha quer comprar" (José Cândido de Lacerda Coutinho, 1868, Santa Catarina); "O marinheiro escritor" (Qorpo Santo, 1866, Rio Grande do Sul); todas disponíveis na Biblioteca Digital de Peças Teatrais (http://www. bdteatro.ufu.br/index.php). Peças hispânicas analisadas: "La pobre Gente" (Florencio
} 
posto que, ao traduzir esse gênero, é necessário conhecer a sua estrutura e funcionalidade em ambas as línguas e culturas envolvidas, a fim de identificar semelhanças e/ou diferenças. Ainda, a análise foi baseada no dispositivo didático para modelização do gênero, proposto por Barros (2012, p. 161). À guisa de sistematização, apresenta-se o modelo elaborado para o gênero peça teatral de comédia, no que diz respeito às capacidades de linguagem:

\section{QUADRO 2}

Modelo didático do gênero peça teatral de comédia

\begin{tabular}{|c|c|}
\hline $\begin{array}{l}\text { Capacidades } \\
\text { de linguagem }\end{array}$ & $\begin{array}{c}\text { Modelização do gênero peça teatral de comédia } \\
\text { (Hispânicas e Brasileiras) }\end{array}$ \\
\hline $\begin{array}{l}\text { Plano da } \\
\text { situação } \\
\text { de ação de } \\
\text { linguagem }\end{array}$ & $\begin{array}{l}\text { - É um gênero escrito, muitas vezes, com marcas de oralidade, uma vez que objetiva } \\
\text { ser lido pelo público geral ou especializado e/ou encenado por atores. } \\
\text { - Pertence à esfera artística literária teatral, assim, pode apresentar figuras de linguagem } \\
\text { e características de uma determinada escola literária. } \\
\text { - Geralmente, quem o produz são dramaturgos, assumindo o papel discursivo de } \\
\text { quem produz uma obra artística para ser encenada, indicando características do } \\
\text { ambiente, figurino e atitudes dos atores, por meio das didascálias ("acotaciones") e } \\
\text { desenvolvendo histórias por meio das falas das personagens. } \\
\text { - Geralmente, os destinatários são diretores de teatro, atores e o público em geral, } \\
\text { assumindo o papel de receptores de uma obra teatral, interpretando o enredo, } \\
\text { identificando as relações entre as personagens, etc. } \\
\text { - O tema dos textos deste gênero é variado, podem tratar de histórias fictícias, histórias } \\
\text { baseadas em fatos reais, retratar relações humanas, críticas sociais de uma época } \\
\text { específica, romance, etc. (no caso das comédias, os temas são tratados com humor } \\
\text { e/ou ironia); } \\
\text { - A relação entre enunciador (autor) e destinatário não é explícita, visto que o } \\
\text { enunciador não fala diretamente aos seus leitores, expressa suas opiniões através das } \\
\text { personagens ou indicações cênicas. } \\
\text { - Em épocas mais antigas, o principal suporte era impresso escrito. Atualmente, há em } \\
\text { versões digitalizadas. } \\
\text { - Textos deste gênero podem ser encontrados em bibliotecas, livrarias, blogs, acervos } \\
\text { eletrônicos, etc. }\end{array}$ \\
\hline
\end{tabular}

Sánchez, 1908, Uruguai); "Los mirasoles” (Julio Sánchez Gardel, 1911, Argentina); "El héroe Galopante" (Nemesio Canales, 1923, Porto Rico); "El nido ajeno" (Jacinto Benavente, 1894, España); "Pueblecito" (Armando Mook, 1917, Chile). 


\begin{tabular}{|c|c|}
\hline & $\begin{array}{l}\text { - Nas falas das personagens, pode-se encontrar o uso de metáforas e/ou ironias } \\
\text { (“AMBROSINA: (Rindo-se.) Que bela frase!”). Além disso, na peça escrita em } \\
\text { verso, pode-se encontrar o uso de rimas. } \\
\text { - O tom dos textos deste gênero é mais coloquial, familiar e humorístico. } \\
\text { - Nestes textos, a voz predominante é a das personagens, que, geralmente, advêm do } \\
\text { senso comum. Nas didascálias, pode-se dizer que é a voz do autor, já que não fazem } \\
\text { parte dos diálogos. } \\
\text { - O processo de modalização do discurso mais frequente é o apreciativo e o deôntico. } \\
\text { - Não há elementos paratextuais. }\end{array}$ \\
\hline $\begin{array}{l}\text { Plano } \\
\text { discursivo }\end{array}$ & $\begin{array}{l}\text { - O tipo de discurso predominante é o dialogal, mas, também, é composto por } \\
\text { sequências descritivas nas didascálias (indicações cênicas) que são identificadas por } \\
\text { marcas tipográficas (parênteses, negrito, itálico, letras maiúsculas etc.). } \\
\text { - Os diálogos são interativos entre as personagens, essas se reportam explicitamente } \\
\text { por meio de nomes próprios e/ou formas de tratamentos para 2a pessoa (em momento } \\
\text { algum o emissor (autor/a) interage diretamente com o(s) leitor(es), mas pode fazê-lo } \\
\text { por meio das personagens. Há ausência de narrador. } \\
\text { - O tempo e o espaço são identificados através das didascálias e dos diálogos entre as } \\
\text { personagens. } \\
\text { - Este tipo de texto apresenta título e/ou subtítulo, nome do autor, pode conter } \\
\text { dedicatória, data de encenação, lista de personagens com indicação dos nomes de } \\
\text { atores ou não. Ademais, apresenta um prólogo (frases curtas indicando o ambiente } \\
\text { inicial da peça) e organiza-se em Atos (de um a quatro atos, no caso das comédias } \\
\text { analisadas), que se dividem em cenas de acordo com as entradas e saídas de } \\
\text { personagens. Não acompanha fotos ou imagens. } \\
\text { - Os textos apresentam sequências dialogais escritas em prosa (no caso das peças } \\
\text { analisadas, somente uma peça brasileira era escrita em verso) mas, os textos deste } \\
\text { gênero, também, podem ser escritos em verso e/ou em forma de monólogos com ou } \\
\text { sem interações com a "plateia" ou destinatário, por parte das personagens. }\end{array}$ \\
\hline $\begin{array}{l}\text { Plano das } \\
\text { propriedades } \\
\text { linguístico- } \\
\text { discursivas }\end{array}$ & $\begin{array}{l}\text { - As retomadas textuais são realizadas, predominantemente, por pronomes pessoais } \\
\text { ou de tratamento e por repetições dos nomes das personagens; } \\
\text { - Os tempos verbais são variados, porém, há predominância de verbos no presente do } \\
\text { indicativo, imperativo ou gerúndio, este último comum nas didascálias. } \\
\text { - O tipo de conectivo mais utilizado é o espacial (Aquí, "Allá", "na sala", "a mesma } \\
\text { sala", "en el comedor de..."; "de la calle" etc.); }\end{array}$ \\
\hline
\end{tabular}


\begin{tabular}{|l|} 
- A maioria dos textos apresenta a variedade linguística de seu país ou região da época de \\
publicação das obras, expressada pelo uso de regionalismos no léxico e/ou sintáxe ("Me \\
caso con Cristóval!" - expressão porto-riquenha da época; "voseo chileno completo" - \\
marca de regionalismo campesino; "mano", etc). Dependendo do contexto da obra e da \\
relação entre as personagens, há uma linguagem mais ou menos informal. Embora, no \\
geral, predomine uma linguagem coloquial da época das obras. ("azougue" - léxico do \\
Português da época, significa indivíduo esperto, rápido; "tílburi" - léxico do Português \\
da época para indicar um tipo de carruagem, etc.); \\
- As escolhas lexicais são variadas, com a presença de adjetivos nas didascálias, \\
indicando características sentimentais ("molestado", "conmovida", etc.) e verbos de \\
ação ("corre", "sale", "va"); \\
- O texto está marcado por sinais de pontuação que indicam as interações dialogais \\
por meio do discurso direto, tais como o travessão nas falas das personagens, sinais \\
de exclamação e interrogação, identificando mudanças de entonação, e reticências, \\
indicando pausas. As didascálias trazem marcas tipográficas que as separam das falas \\
das personagens, tais como parênteses, letras em itálico, em negrito ou em maiúsculo.
\end{tabular}

Fonte: Autoria própria.

Esse modelo didático do gênero peça teatral de comédia poderá auxiliar nas decisões sobre o que abordar nos módulos da SD. Esses se centrarão nas dificuldades apresentadas na análise pré-tradutória e na primeira produção e, ainda, poderão girar em torno de cada capacidade de linguagem especificada no modelo didático do gênero apresentado. O modelo, também, pode servir de base para a elaboração da lista de constatações. Essa, nas palavras de Gonçalves e Ferraz (2014, p. 219), pode ser formulada pelo professor ou pelos estudantes e tem o objetivo de facilitar a avaliação das produções da SD, inclusive, na hora de comparar a primeira e a última produção. Servindo, assim, como um instrumento de autorregulação da aprendizagem.

Prosseguindo com o objetivo desta seção, exemplificar-se-á a definição de um encargo de tradução, o qual consistirá na apresentação da situação comunicativa da SD. Para tal decisão, é necessário ter em mente os objetivos estipulados para a SD, pois a situação de comunicação guiará todas as decisões durante o processo de tradução. Assim, seria interessante aproximar esta situação a um contexto real, a fim de cumprir os princípios da comunicabilidade e autenticidade (esclarecidos na primeira seção). Logo, retomando as características do encargo de tradução didático proposto por Nord (1996) e, a partir do contexto de ensino descrito no início desta seção, elaborou-se o seguinte encargo de tradução: 


\section{QUADRO 3}

Definição do encargo de tradução didático para a SD

\begin{tabular}{|l|l|}
\hline $\begin{array}{l}\text { 1. A função ou funções comunicativas } \\
\text { do TM }\end{array}$ & $\begin{array}{l}\text { Adaptar obras teatrais hispânicas de comédia } \\
\text { à realidade brasileira. }\end{array}$ \\
\hline $\begin{array}{l}\text { 2. Os destinatários do TM } \\
\text { 3. As condições temporais e locais } \\
\text { previstas para a recepção do TM }\end{array}$ & Século XXI, ano 2016; Brasil. \\
\hline \begin{tabular}{l} 
4. O meio pelo qual será transmitido o TM \\
\hline 5. O motivo pelo qual se produz o texto
\end{tabular} & $\begin{array}{l}\text { Aivulgar obras teatrais hispânicas para o } \\
\text { público brasileiro na internet. }\end{array}$ \\
\hline
\end{tabular}

Fonte: Autoria própria.

Por ser uma SD, a partir da tradução funcionalista, a seleção do TB para a tradução deve ser criteriosa, já que por meio dela poderão ser abordados mais ou menos problemas de tradução culturais, pragmáticos, linguísticos e/ou extraordinários, principalmente, por tratar-se de um gênero textual literário. Assim, alguns critérios que podem servir para selecionar o TB são:

1. País de origem do texto, visto que há diversos países que possuem a língua espanhola como oficial. Ademais, a variedade linguística utilizada pode ser desconhecida pelos estudantes, fato que exigirá maior pesquisa e competência técnica;

2. Período de publicação do texto, posto que textos mais antigos poderão requerer maior adaptação cultural, pragmática e linguística, além de técnicas e materiais de investigação;

3. Extensão do texto, uma vez que, a depender do nível dos estudantes, textos longos poderão causar maiores dificuldades textuais, de competência e/ou profissionais.

4. Tema do texto, se muito distante da realidade dos aprendizes poderá gerar maiores dificuldades de competência e problemas pragmáticos, culturais e/ou linguísticos.

A fim de encerrar esta seção, sistematizou-se a proposição de um projeto inicial de SD com a tradução funcional do gênero peça teatral de comédia, na figura 3: 
FIGURA 3 - Esquema da SD a partir da tradução funcional

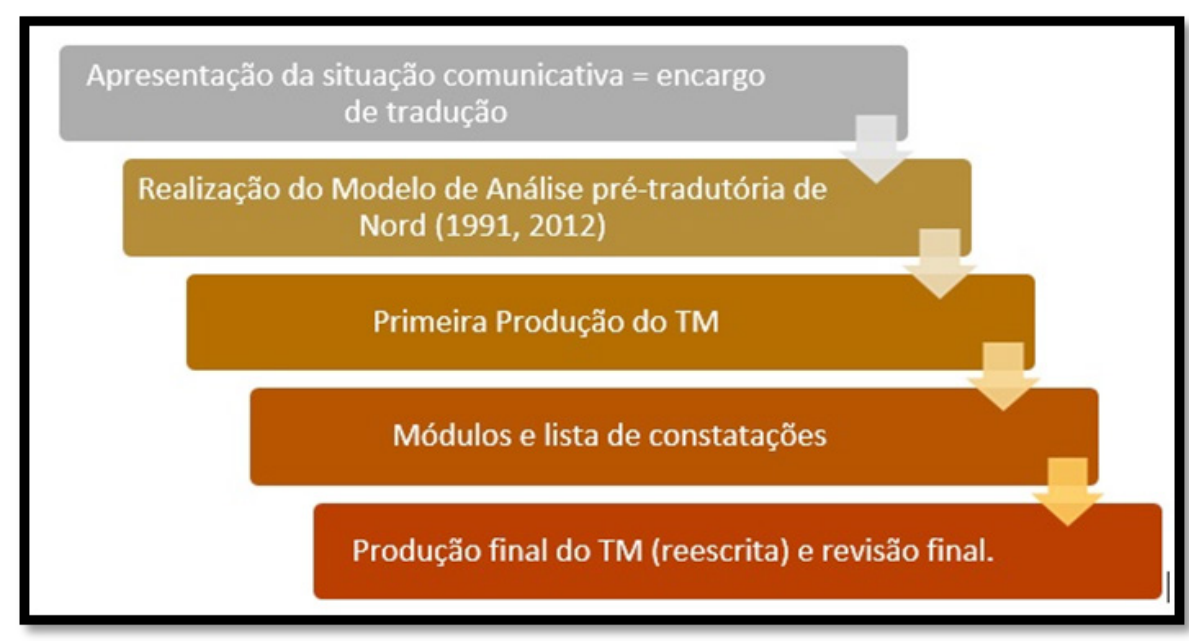

Fonte: Autoria própria.

\section{Considerações finais}

Por meio do que foi discutido neste artigo, vislumbra-se a aproximação entre a Tradução Funcionalista e Estudos sobre Gêneros Textuais, no âmbito do Ensino de Tradução. Assim, ao revisar alguns direcionamentos da Didática da Tradução Funcionalista, mostrou-se a possibilidade de aliar o dispositivo de SD com a tradução funcional de gêneros textuais autênticos. O próprio modelo de análise pré-tradutória, proposto por Nord (2012), contempla as capacidades de linguagem, tão exploradas no procedimento de SD com vistas à apropriação de gêneros textuais.

A SD, inicialmente, proposta pelo Grupo de Genebra e adaptada pela vertente brasileira, como mostram Costa-Hürbes e Simioni (2014), não objetiva ser um modelo fechado em si mesmo, tal como um manual para o ensino de gêneros textuais. Portanto, devido a sua flexibilidade e adaptação ao contexto de ensino em que se aplicará, pondera-se que a sua realização, no contexto de Ensino de Tradução, poderá proporcionar ao futuro tradutor o conhecimento sobre diferentes gêneros textuais e seu funcionamento, nas distintas culturas envolvidas na tradução. 
O projeto inicial da SD, ilustrado neste artigo, encontra-se em fase de aplicação, desse modo, não apresentamos análise de corpus, composto das primeiras traduções, módulos e traduções finais da SD. No entanto, realizamos o modelo didático do gênero peça teatral por meio das orientações de Cristóvão (2010) e Barros (2012), as quais sugerem os seguintes passos: 1. Levantar o perfil da situação de ensino, 2. Recolher orientações da literatura especializada sobre o gênero explorado, 3 . Selecionar corpora para a análise de características inerentes ao gênero a ser ensinado. Por último, exemplificamos a definição de um encargo de tradução/ apresentação da situação comunicativa e sugerimos critérios para a seleção de textos que possam ser usados em uma SD, a partir da Tradução Funcionalista.

Esperamos que a aplicação da SD, ilustrada aqui, possibilite: (i) o desenvolvimento de capacidades de linguagem na língua-base e na língua-meta; (ii) a apropriação do gênero peça teatral; (ii) a abordagem de dificuldades e problemas de tradução específicos. Também, esperamos fomentar uma reflexão epilinguística e a compreensão da tradução como um processo circular, no qual o tradutor pode revisar todas as etapas do processo tradutório.

\section{Referências}

BARROS, E. M. D. Gestos de ensinar e de aprender gêneros textuais: a sequência didática como instrumento de mediação. 2012. 368 f. Tese (Doutorado em Estudos da Linguagem) - Centro de Letras e Ciências Humanas, Universidade Estadual de Londrina, Londrina, 2012.

BARROS, E. M. D. O gênero textual como articulador entre o ensino da língua e a cultura midiática. In: NASCIMENTO, E. L. Gêneros textuais: da didática das línguas aos objetos de ensino. Campinas: Pontes Editores, 2014. p. 137-168.

BEAUGRANDE, R. A. de; DRESSLER, W. U. Introducción a la Lingüística del Texto. Barcelona: Ariel, 1981.

CASSANY, D. Describir el escribir. Cómo se aprende a escribir. 17. ed. Barcelona: Paidós, 2010. 
COSTA-HÜRBES, T.C.; SIMIONI, C.A. Sequência didática: uma proposta metodológica curricular de trabalho com os gêneros discursivos/ textuais. In: BARROS, E. M. D.; RIOS-REGISTRO, E. S. (Org.). Experiências com sequências didáticas de gêneros textuais. Campinas: Pontes Editores, 2014.

CRISTOVÃO, V. L. L. Sequências didáticas para o ensino de línguas. In: DIAS, R; CRISTOVÃO, V. L. L. (Org.). O livro didático de língua estrangeira. Múltiplas perspectivas. Campinas: Mercado de Letras, 2009. p. 305-344.

CRISTOVÃO, V. L. L. O gênero quarta capa no ensino de inglês. In: DIONISIO, A. et al. (Org.). Gêneros textuais e ensino. São Paulo: Parábola, 2010. p. 105-116.

DEMÉTRIO, A. P. C. A tradução como retextualização: uma proposta para o desenvolvimento da produção textual e para a ressignificação da tradução dentro do ensino de LE. 2014. 198f. Dissertação (Mestrado em Estudos da Tradução) - Centro de Comunicação e Expressão. Universidade Federal de Santa Catarina, Florianópolis, 2014.

DOLZ, J.; SCHNEUWLY, B. Genres et progression en expression orale et écrite: éléments de réflexions à propos d'une experience romande. Enjeux, 37/38, 1996, p.49-75.

DOLZ, J.; SCHNEUWLY, B. Pour um enseignement de l'oral: imitation aux genres formels à l'école. Paris: ESF, 1998.

DOLZ, J.; NOVERRAZ, M; SCHENEUWLY, B. Sequências didáticas para o oral e a escrita: apresentação de um procedimento. In: ROJO, R.; CORDEIRO, G. S. (Org.). Gêneros orais e escritos na escola. Campinas: Mercado de Letras, 2004. p. 95-128.

GONÇALVES, A. V.; FERRAZ, M. R. R. Ferramentas didáticas e ensino: da teoria à prática de sala de aula. In: NASCIMENTO, E. L. Gêneros textuais: da didática das línguas aos objetos de ensino. Campinas: Pontes Editores, 2014. p. 209-229.

LAIÑO, M. J. A tradução pedagógica como estratégia à produção escrita em LE a partir do gênero publicidade. 2014. 234f. Tese (Doutorado em Estudos da Tradução) - Centro de Comunicação e Expressão. Universidade Federal de Santa Catarina: Florianópolis, 2014. 
MARCUSCHI, L. Gêneros textuais: definição e funcionalidade. In: DIONISIO, A. et al. (Org.). Gêneros textuais e ensino. São Paulo: Parábola, 2010. p. 19-38.

MOSQUERA ROA, S; SANCHEZABCHI, V. Las secuencias didácticas de género textual en ELE. Perspectivas para una formación docente. In: GARCÍA-AZKOAGA, I. M.; IDIAZABAL, I. (Ed.). Para una ingeniería didáctica de la educación plurilingüe. Bilbao: Universidad del País Vasco, Servicio Editorial, D.L, 2015.

NORD, C. Text Analysis in Translation: theory, methodology and didactic application of a model of translation-oriented text analysis. Tradução de Christiane Nord e Penelope Sparrow. Amsterdam; Atlanta: Rodopi, 1991.

NORD, C. El error en la traducción: categorías y evaluación. In: HURTADO ALBIR, A. Estudios sobre la traducción. Castelló: Universitat Jaume I, 1996. p. 91-107. Disponível em: <http://goo.gl/SdW35b >. Acesso em: 20 fev. 2015.

NORD, C. Traduciendo funciones. In: HURTADO ALBIR, A. (Ed.). Estudios sobre la traducción. Castelló: Publicacions de la Universitat Jaume I, 1994. p. 97-112.

NORD, C. El funcionalismo en la enseñanza de traducción. Mutatis Mutandis, v. 2, n. 2, p. 209-243, 2009. Disponível em: <http:/goo. gl/7kdLWX>. Acesso em: 3 mar. 2015.

NORD, C. Texto base-texto meta. Un modelo funcional de análisis pretraslativo. Tradução e adaptação de Cristiane Nord. Castelló de la Plana, Espanha: Publicacions de la Universitat Jaume I, 2012.

PIETRO, J. F.; SCHENEUWLY, B. O modelo didático do gênero: um conceito da Engenharia Didática. In: NASCIMENTO, E. L. Gêneros textuais: da didática das línguas aos objetos de ensino. Campinas: Pontes Editores, 2014. p. 51-81.

PINTO, A. P. Gêneros discursivos e ensino de língua inglesa. In: DIONISIO, A. et al. (Org.). Gêneros textuais e ensino. São Paulo: Parábola, 2010. p. 51-62.

REISS, K.; VERMEER, H. J. Fundamentos para una teoría funcional de la traducción. Tradução de Sandra García Reina e Celia Martín de León. Madrid: Ediciones Akal, 1996. 206p. 
ROMÃO, T. L. C. Definições de Tradução e Evolução dos Estudos Tradutórios. In: MATTES, M; THEOBALD, P. Ensino e Cultura Contemporânea. Fortaleza: Edições UFC, 2010a. p. 31-46.

ROMÃO, T. L. C. Ilusão teatral versus Realidade Tradutória: os extremos da tradução teatral. In: LÚCIO, A. C. M.; SCHNEIDER, L. (Org.). Cultura e Tradução: interfaces entre teoria e prática. João Pessoa: Ideia, 2010b. p. 51-70.

RYNGAERT, J. P. Introdução à análise do teatro. Tradução de Paulo Neves. São Paulo: Martins Fontes, 1995. 192 p.

STUTZ, L; CRISTÓVÃO, V. L. L. A construção de uma sequência didática na formação docente inicial de língua inglesa. Revista Signum: Estud. Ling., Londrina, v. 14, n. 1, p. 569-589, 2011.

TRAVAGLIA, N. G. Tradução como retextualização: a tradução numa perspectiva textual. 2. ed. Uberlândia: EDUFU, 2013. 308 p.

UBERSFELD, A. Para ler o teatro. Tradução e coordenação de José Simões. São Paulo: Perspectiva, 2005. 